\title{
The Last Years of the Navigation Acts
}

I.

RECENT historians, economic as well as general, have neglected the $\mathrm{R}$ antecedents of the repeal of the navigation laws. The Act of 1849 is usually, and in the main rightly, treated as an appendix to the story of the fall of the corn laws, as " a logical sequence to the freeing of trade ';' but this alleged logical necessity has apparently acted as a deterrent from detailed inquiry into subsidiary causes and attendant circumstances. No doubt the whole system was infirm in the nineteenth century, though its infirmity was not so generally recognised as has sometimes been suggested." No doubt, too, it was doomed after the measures taken by Wallace and Huskisson between 1821 and 1825 ; but its declining years deserve more attention than they have received.

At no time were all the rules affecting navigation to be found in a single statute or group of statutes. The great Navigation Act itself ${ }^{3}$ only received its final character through the passing of a series of supplementary acts. Of these the chief are the statute for preventing frauds and regulating abnses in his majesty's customs, ${ }^{4}$ which prohibited the importation of a long list of staple wares into England from the Netherlands or Germany in any sort of ships or vessels whatsoever, and declared that a foreignbuilt ship could not become British by purchase; and a statute ${ }^{\circ}$ which further regulated the plantation trade and forbade the export of the enumerated plantation wares to Ireland." The regulation of the taxes levied on goods brought legally in foreign bottoms was part of the customs law ; bat port and harbour dues, which before Huskisson's time were usually preferential, were often determined by local enactments. It will be well however to examine first and most

1 Political History of England, xii. 88.

= E.g. by Dr. Cunningham, Grovth of English Industry and Commerce, ii. 830.

12 Car. IJ, c. 18.

413 \& 14 Car. II, c. 11.

15 Car. П, c. 7.

- Other details of the plantation trede are dealt with in 22 and 23 Car. II, c. 26 and 25 Car. II, c. 7 : 80 Egerton, Short History of British Colonial Policy, p. 71. 
carefully the consolidating Acts of 1825 and 1833, the Navigation Acts properly so called, which contain the central principles of the code as it existed at the beginning of the last phase. ${ }^{7}$ The outlying parts of the code, the matter that had dropped out of it, and the more important legal and administrative rules related to it can most conveniently be treated in connexion with these Acts.

The Act of 1825, as its preamble explains, was rendered necessary by the generel recasting of the customs law resulting from Huskisson's reforms. It begins with a list of goods, the produce of Europomasts, timber, boards, salt, pitch, tar, tallow, rosin, hemp, flax, currants, raisins, figs, prunes, olive oil, corn or grain, potashes, wine, sugar, vinegar, brandy, or tobacco - which may not be imported into the United Kingdom, to be used therein, save in British ships, or in ships of the country of which the goods are the produce, or in ships of the country from which the goods are imported. This list, not to be confused with the list of goods which, under the old regime, the colonies were obliged to export to the mother country, is a pale reflexion of the earlier enumeration clauses, an ontcome of the Acts of 1822 and the following years. The special attack on the Duteh, contained in the statute of frauds in the customs, has gone ; enumerated goods may be imported in any bottoms, if they are warehoused for re-exportation, and ships of the country from which the goods are imported are put on the same footing as ships of the country of which the goods are the produce. ${ }^{8}$ This last clause was a matter of convenience pure and simple. There had been endless trouble to the English officials and merchants involved in the attempt to ferret out whether or no goods coming from a given country, in its own ships, were its own produce. For some reason, which it is difficult to explain, the list was considerably extended in 1833. Salt, pitch, rosin, potashes, sugar, and vinegar disappear ; but in their place are inserted wool, shumac, madder, vanilla, brimstone, oak bark, cork, oranges, lemons, linseed, rapeseed, and clover seed. It must be assumed that in the interval cases of the import of (say) brimstone from Sicily, or oak bark from Spain, in Dutch, Hanse, or other ships had attracted the attention of the board of trade. The list-which was repeated verbatim in the Act of 1845 - became curiously arbitrary at the lest. When devised in the seventeenth century it was meant to include, and did actually include, the chief

' 6 Geo. IV,. c. 109 and 3 \& 4 Will. IV, c. 54. Both are entitled, as is the final consolidating Act, 8 \& 9 Vict. c. 88, Acts 'for the encouragement of British shipping and of navigation.'

- A common mistake in descriptions of the law as Huskisson found it is the statement or implication that it prohibited the import of all European goods save in Britigh or 'producer' ships : e.g. Political History of England, xi. 203 ; Cambridge Mod. Hist. x. 585. This was the rule of 1651 , not that of 1660 . Only the enumerated goods and goods from Russia or Turkey had to come in British or ' producer' ships. Seo M'Govney, The Navigation Acts and Eutropean Trade, in Amer. Hist. Rev. ix. 4.

voL. XXV.—NO. XCIX. 
bulky articles of European commerce. The revision of 1839 shows that this intention had not at that date been abandoned. But when the import of cattle became legal, under Peel's administration, they were not inserted. Flour, fish, and many other goods were not on the list, and the possibly accidental omission of sugar in 1839 allowed European refined sugar, which was treated as a manufacture of the refining country, to come here in any bottoms whatever. ${ }^{9}$

The great Navigation Act had absolutely prohibited the import of Asiatic, African, or American goods by way of European ports or in non-British ships." This latter rule had been rendered obsolete by the changed condition of America, resulting from the independence first of the United States and then of the Spanish colonies. Its various infringements receive a general sanction in the Act of 1825 . Non-European produce, with certain exceptions, may come only in British ships, or in 'ships of the country ... of which the goods are the produce and from which they are imported.' Here is a slight difference between the law for America and that for European ' and 'instead of an 'or.' A Portugnese ship may bring Spanish wine from Lisbon, but a United States ship may not bring Cuban sugar from New York.

In principle, the rule that non-Europeen goods might not come from European ports even in British ships was retained. Its object was to give to British ships the long voyage instead of the short one. This remained to the end one of the most really operative clauses of the law. The exceptions, which are intricate, concerned the Mediterranean. Broadly speaking, Asiatic or African wares might come in British ships by way of non-Asiatic and non-African ports in the Mediterranean; though the Act of 1893 cantiously added that such wares must be bona fide articles of Mediterranean trade, that is, must not have come into that sea by way of the Atlantic."

The coasting trade of the United Kingdom wes of course retained for British ships, and the rule, which in all previous Acts hed applied only to goods, was made to cover passengers in 1845 . No ship was recognised as British, for that or any other purpose, unless properly registered, commanded by a British subject, and manned by a crew ' whereof three-fourths at least are British seamen.' A native of the East Indies was not a British seaman. A foreign ship, to secure recognition, had to be ' of the build of or prize to ' the country

- Leferre's paper in the Report of the Select Committee on the Navigation Laves, 1847, q. 5, 6. Soe also Rioardo, Anatomy of the Navigation Laws, 1847, p. 72, and $A$ Short Review of the Biofory of the Navigation Laves [by Sir Stafford Northcote], 1849, p. 60.

10 There were some excoptions even here; for there was no end to the complexity of the law, Northoote, p. 29 ; Shillington and Chapman, Commercial Relations of England and Portugal, p. 285.

"Further, bullion and jewels were subject to no rules; wares of Asiatic Turkey might come in the shipg of Turkey in Europe; after 1833 silk and moheir yarn from any part of Anis might come in Turkish ships from Levant porta. 
concerned, with her master and three-fourths of her crew natives of that country. ${ }^{12}$

Both in the Acts of 1825 and 1833 the rules for the colonial trade are few and simple. The legal situation was however more complex, though hardly more burdensome, than the Acts indicate. Long before Huskisson's time the old colonial system had been breaking up, and a series of acts and treaties, starting from the Free Ports Act of 1766 , had eased the colonial trade. So little galling, it has been said, were the bonds which remained that Huskisson's reforms and the final repeal of the Navigation Laws 'aroused little interest in the colonies, because the restrictions that had been removed had caused no serious inconvenience.' ${ }^{15}$ By 1825 the enumerated exports are extinct : the colonies may send their goods where they please. Foreign goods from foreign countries may enter the colonies (through the free ports, but all the important ports were free) in British ships or in ships of the producing-not in this case of the exporting - country, and foreign ships may carry colonial goods anywhere, provided always that the foreign country grants reciprocal privileges. $^{\text {it }}$ Not all foreign countries did. The chief exceptions to the end were France and Spain, who enjoyed only limited trading rights in the colonies, with Holland, Belgium, and Sardinia, who enjoyed no such rights at all. The grant of trading rights was usually made by order in council, occasionally by treaty. ${ }^{15}$ The East Indies were not a British possession within the meaning of the Acts. All ships of the East India Company were 'British,' though foreigners could hold its stock; and there were other exceptions to the registration laws. Under an eighteenth century statute, never repealed but not mach used, the directors might regulate as they thought fit the trade of the ships of friendly powers; and by a special agreement of 1819 ships of the United States might clear with cargoes from Great Britain for the East. ${ }^{16}$

Huskisson's reciprocity treaties dealt mainly with matters which were outside the true Navigation Laws, though the restrictions which they superseded had effectually stiffened the navigation system.

12 The chief registration laws of the period are, for Act of 1835, 'To amend and consolidate . . laws relating to merchant seamen and for forming and maintaining a register,' 5 \& 6 Will. IV, c. 19 and 7 \& 8 Vict. c. 112 ; Registration of Ships, $3 \& 4$ Will. IV, c. 55 and $8 \& 9$ Vict. o. 89.

1 Devidson, Commercial Federation and Colonial Trade Policy, p. 18. Professor Egerton takes the same view, paying no attention to the laws in the nineteenth century : British Colonial Policy, pp. 258, 332.

"If it had colonies, it had to grant corresponding privileges therein ; if it had none, to concede most-favoured-nation treatment in all commeroial relations.

11 The full lists of countries admitted, partially admitted, and ercluded is given by Ricardo, p. 125. The bargaining rules are not in the Navigation Aots but in the corresponding series of Possessions Acte, 6 Geo. IV, c. 114, 3 \& 4 Will IV, c. 59, 8 \& 9 Vict. c. 88.

10 Leferre's peper, ubi supra; also the Report of 1847, q. 116, 128, 129. 
These restrictions were due to the various differential charges on foreign ships-port, tonnage and pilotage dues-and on the goods which they brought, as well as to the practice of refusing to the owner of goods legally shipped in foreign bottoms certain drawbacks and bounties of the old customs system. How the United States secured equal port and customs treatment for their ships in 1815, and how Prussia and other powers, including again the United States, threatened or began reprisals between 1817 and 1823 is well known. The results were the Acts of $4 \mathrm{Geo}$. IV, c. 77, 'to authorise his Majesty, under certain circumstances, to regulate the duties and drawbacks on goods imported or exported in foreign vessels, and to exempt certain foreign vessels from pilotage,' and of $5 \mathrm{Geo}$. IV, c. 1 , ' to indemnify all persons concerned in advising, issuing, or acting under a certain order in council for regulating the tonnage daties on certain foreign vessels ; and to amend' the Act of the previous session.

In all the earlier treaties and orders connected with these Acts the Navigation Laws proper are scrupulously safeguarded, though reciprocity made a serious breach in the navigation system. ${ }^{17}$ A typical treaty and order of the early series and of the widest scope legally possible are those relating to Prussia dated 2 April and 25 May 1824: charges on vessels of the contracting parties in one another's havens are to be equalised ; goods, the produce of either, whose import or export is not specially prohibited, may be moved to and fro in the ships of either power indifferently ; no special duties shall be levied on any articles, whether the produce of the contracting parties or not, merely because they come in the ships of the other party when their import is otherwise legal (this clause fully safegaards the Navigation Acts); bounties, drawbacks, or allowances shall not be withheld by England merely because goods legally exportable are shipped in Prussian rather than in English bottoms. Such an arrangement had the effect of rendering the direct trade with countries admitted to the fall privileges of reciprocity perfectly free and equal, customs duties apart. Already before 1830 Prussia, Denmark, Sweden, the Hanse towns, Mecklenburg, Hanover, the United States, France, Austria, and most of the new South American republics had taken advantage of the system, although not all of these powers enjoyed the fullest possible trading privileges in the British empire. Prussia, by order in council of 3 May 1826, secured the right to trade with the colonies in return for most-favoured-nation

\footnotetext{
"Nearly all the treaties and orders of the period are collected in Macgrogor, Commercial Statistics, 4 vols. 1844. It was found in practice that an order alone could not get rid of some of the local differential dues, hence the need for treaties-which were also desirable as more permanent than orders. See below, p. 486. Condensed references to these treaties are sometimes mislesding, e.g. Political History of England, ri. 207, 'owing to Huskisson's enlightened policy the old Navigation Laws had been repealed upon the condition of reciprocity.'
} 
treatment of British commerce and navigation. Many other powers followed suit, but France, as has been said, did not enjoy full rights of entry into the colonial trade ${ }^{18}$ because of her own colonial policy ; and there were others in the same case. Besides the wholly or partially excluded, there were also the penalised powers. The Dutch, who never gained entry to the colonial trade, were admitted to equality of port charges in the United Kingdom by order in council of November 1824; but two years later Canning 'clapped on Dutch bottoms just 20 per cent.,', ${ }^{19}$ and the 20 per cent. extra duty was maintained until 1837. It must not be forgotten that admission to the colonial trade did not meen admission on terms similar to those granted to the ships and goods of the mother country. Colonial differentials in favour of British trade remained in full force till 1846.

The last of the early reciprocity treaties of what may be called the Huskisson type was that concluded by the earl of $A$ berdeen with Austria in December 1829. ${ }^{20}$ During the next three years England and the continental powers had other things than commercial negotiations to think of. The Belgian revolution and the persistent ensuing friction between King William of Holland and bis neighbours postponed for seven years the readjustment of economic relations between England and the Dutch. During the years 1830-6 only three commercial treaties were concluded; two with Frankfort, in 1832 and 1835, and one with Venezuels in 1834. None of these are in themselves of very grest interest ; but those with Frankfort open out the whole question of the relations between England and the Zollverein-a question which dominated the commercial diplomacy of the time and was intimately connected with the break up of the navigation system. It will be well therefore to deal first with the Dutch treaty of 1837, and then to take ap the Frankfort treaties in connexion with the Austrian treaty of 1898, the Hanse and Prussian (Zollverein) treaties of 1841, and the Mecklenburg, Hanover, and Oldenburg treaties of 1844 , for this whole series forms a part of the Zollverein question.

Palmerston cared little enough for commercial matters. 'On the economic or the moral side of national life, in the things that make a nation rich and the things that make it scrupulons and just,' says Viscount Morley, 'he had only limited perceptions and moderate

1" French ships might only import certain classes of French goods and only into our American and West Indian colonies : Order in council of 3 May 1826, Macgregor, i. 241 .

1" The correct text of Cunning's famous rhyming despatch of 31 January 1826 is printed by Sir Harry B. Poland in Noles and Queries, 9th ser. x. 270, + Octobcr 1902.

:o It was based on the Prussian treaty. Aberdeen refused to put any reference to the colonies into the treaty - though he opened the colonial tracle to Austria by order in council-because Austria had no colonies : Aberdeen to Esterhazy, 20 August 1829, Foreign Office, Austria, 218. 
faith." ${ }^{21}$ His commercial despatches are few, and follow very closely the briefs supplied to him by the board of trade. The relatively subordinate position of the president of the board rendered it very difficult for any man holding that post, who was not a statesman of the first rank, to initiate decisive negotiations when the foreign secretary was indifferent. And the whig presidents-Lord Auckland (1880-4), Poulett Thomson (1834-9), Labouchere (1899-41)though men of ability were not the equals of Huskisson. It may well be that the barrenness of the thirties, from the present point of view, was due rather to accident and the state of international politics than to the defects of the whig cabinets ; but it is at least noteworthy that, in commercial negotiations as in finance, these cebinets achieved so little. 'The two failures were not without connexion; for no striking commercial treaties could be negotiated unless the cabinet was prepared to deal vigorously with the tariff and kindred matters, and the papers of the foreign office and board of trade show no traces of vigorous initiative, save on the part of the permanent officials. ${ }^{22}$ It is the old tale of the great whig administration : the utilitarians in the background.

The negotiations with Holland in 1836-7 arose out of complaints addressed to the board of trade by certain East India merchants, who alleged that the Dutch were failing to carry out obligations entered into by them in a treaty signed on 17 March 1824 for the regulation of the trade between the East Indian possessions of the two powers. ${ }^{23}$ The matter had long been in hand. As early as 1830 the merchants had secured what they held to be conclusive evidence of the abuse, and in 1833 the English government began to complain. Early in 1886 Palmerston suggested that Holland should refund the overcharge. ${ }^{24}$ Six months later, as nothing had been done, he pointed out that Holland only enjoyed equality of port charges by order in council; that 'all other countries included in that order, with the exception of Belgium, had placed the principles therein recorded under the more formal sanction of treaties,' and that his majesty's Government could not be expected to continue the existing provisional arrangement indefinitely, 'while they required from other countries that such provisional arrangements should be abandoned.' He suggested, at the recommendation of

" Gladstone, i. 387.

z: When Auckland was president and Poulett Thomson vice-president it was the exception for both to attend meetings of 'the board ' (Minutes, Board of Trade, 5, 42). I have not been able to consult the board of trade papers beyond 1837, and those that I have consulted are not very valuable.

2 This treaty. is not one of the reoiprocity series: it relates exclusively to the eastern trade. The tert is given by Macgregor, i. 836. Documents relating to the negotiation of 1836-7 are in Foreign Office, Holland, 188, 204-8.

it Palmerston to Sir E. Disbrowe, 26 January 1836. It was almost impossible to prore the existence of this alleged overcharge: Disbrorre to Palmerston, 21 February 1837. 
the board of trade, that the navigation relations of the two countries might advantageously be regularised by treaty. ${ }^{25}$ This gentle pressure started the negotiation. The Dutch had little to losethat little they succeeded in retaining - and much to gain. In September Palmerston forwarded a draft treaty, stipulating for complete reciprocity of navigation dues and most-favoured-nation treatment in the European dominions of the contracting parties. Incidentally its acceptance would get rid of the 'twenty per cent.' 28 Discussion ranged outside the navigation system, and included contemplated changes in the Dutch tariff and the establishment of consuls in the eastern possessions of the two powers, as well as the question of refunding the overcharge. Nearly all the English proposals found their way into the treaty that was signed after long delay on 27 October 1837, but Disbrowe had to drop his claim to the refund, "a subject which was never touched upon without raising the angry feelings of the king and his ministers.' ${ }^{77}$ When all was done the East Indian grievance remained, and the merchants were still petitioning that the reciprocity guaranteed by the treaty in the case of European trade might be extended effectively to the trade of the East. It is worth noting that one clause, the third, was only accepted by the Dutch king with the greatest reluctance. This clause contained the definition of a Dutch ship, which definition was made to conform to the English law. A 'British' ship had to be British-built, or a lawful prize, and 'owned, navigated, and registered according to the laws of Great Britain.' A 'Dutch ' ship was one Dutch-built, or a lawful prize, "wholly owned by any subject or subjects of the king of the Netherlands' with 'the master and three-quarters of the crew Netherlands subjects.' The king, who had not yet finally abandoned his claims on Belgium, whose country also was somewhat a land of passage, thought that this rigid definition might prove burdensome. But he accepted it, and for the first time since the days of the early Stuarts Holland found herself 'most favoured' instead of most hampered in her trade with England. The treaty was entered into for ten years.

While British commercial diplomacy was in its most inactive stage, between 1829 and 1885, the Zollverein came into existence. The documents hardly justify Treitschke's implication of a sustained and malignant English opposition to the various steps in its creation. Naturally enough the board of trade disliked any prospect of change in the very favourable customs tariffs of such states as Hanover, the Hanse towns, and the city of Frankfort-the emporia for English manufactures and colonial produce; but at the foreign office neither Aberdeen nor Palmerston took the matter very seriously. On the other hand, most of the ambassadors and agents in Germany were

is To Disbrowe, 3 June 1836.

: Ibid. 20 September 1838 .

27 To Palmerston, 21 February 1837. 
hostile, or at least suspicious, towards Prussia, and England as a whole rightly welcomed any scheme that seemed to offer a chance of perpetuating or extending the comfortable tariffs of the agricultural states and trading cities of Northern and Western Germany. True, the Prussian tariff of 1818-9, the foundation of that of the Zollverein, was less rigorous than anything which England could show before the days of Peel ; bat its heavy duties on colonial produce and on certain manufactures were troublesome to the English trader, the more so as they were particularly well enforced. ${ }^{2 *}$ Still more annoying were the varions devices that Prussia adopted to coerce the minor states into accepting her tariff, especially the transit dues on goods crossing Prussian territory. Hesse-Darmstadt was Prussia's first considerable recruit by the treaty of 14 February 1828; for Schwarzburg-Sondershausen hardly counted. The trade of Offenbach, just across the Main from Frankfort in the territory of the grand dachy, at once began to injure that of the free city, and Charles Grant, president of the board of trade, complained a little to Bülow, the Prussian minister in London. ${ }^{29}$ In September of that year the Mitteldeutscher Handelsverein-including Saxony, Hanover, HesseCassel, Brunswick, Weimar, Hamburg, Bremen, Frankfort, and a few others-began by the treaty of Cassel its ill-starred career of opposition to the Prussian league of the north and the BavarianWürtemberg league of the south.

Its birth was blessed by Henry Unwin Addington, our representative in Frankfort, and Hanoverian statesmen were among its most active directors. It was feared that if Prassia absorbed the central states ' our commerce with the interior of Germany would be almost entirely destroyed.' so The new league with its 'free trade' tariff, on the otber hand, would keep the road to the interior open; and ' besides these lawful commercial advantages such a state of things would afford immense facilities for carrying on the contraband trade in the dominions of Prussia, Bavaria, Würtemberg, and Darmstadt,' 31 an unpleasantly cynical admission. Such considerations apart, the attraction of the policy of the league for England was both natural and right. But the attraction was short-lived. First Meiningen and Gotha, then Hesse-Cassel, then Saxony deserted, and by 1831 the

a Milbanke, chargć d'afaires at Frankfort, wrote to Lord Dudley, on 14 March 1828, - the Prusaisn custom house establishment is conduoted with the utmost severity :' Foreign Office, Germany, 28. The duties on woven goods were nominally only 10 to 15 per cent. ; bot being levied by weight they fell rery heavily on coarse materials. These became cheaper as manufacturing processes were perfected, so that in 1844 Maogregor maintained that gome paid as much as 95 per cent. ad valorem: op. cit. i. 547 .

$\Rightarrow$ Treitsohke, Deutsche Geschichte, iii. 637,644.

- Milbanke to Dudley, 24 March 1828.

"Addington to Dudley, 27 May 1828. Treitschke's account of Addington's doings is not seriously exaggerated. I have found no specific instructions for him on this head; but he was not discouraged. 
Middle Union was dead. Hesse-Cassel promptly made terms with Prussia. The absorption of both the Hesses left Frankfort hopelessly isolated, with efficient Prussian customs houses at her very doors on all sides save that facing Nassau. True, the conclusion of the Rhine Navigation Convention between Prussia and Holland in August 1831 made the great river in fact what it had been since 1815 in name, an open road from the North Sea to High Germany, ${ }^{38}$ but Frankfort's difficulty was less to procure sea-borne wares than to dispose of them. So she turned to England, and had no difficulty in concluding a treaty of customs and nevigation in London on 13 May 1832. 'Frankfort,' wrote Thomas Cartwright, our representative there, three years later, 'has all along fought against the Prussian system. The treaty [of 1832] was contracted to obtain support against Prussia and encourage other states to take the same course.' ${ }^{3 s}$ It contained a mutual ten years' guarantee of mostfavoured-nation treatment, whereby of course Frankfort was excluded from coming to terms with Prussia, the usual reciprocity clauses for navigation, and a special concession on England's part connected with the definition of a Frankfort ship : it might be boilt at Frankfort or in Great Britain, and three-quarters of its crew must be Germans, but not necessarily Frankforters. The reason assigned for this favour was the smallness of the Frankfort territory. ${ }^{34}$

Frankfort's hopes that this treaty would encourage the rest were vain. In 1839 Bavaria, Würtemberg, the Thuringian States, and Saxony came to terms with Prussia, and before 1834 was over Frankfort herself, squeezed by Prussia and aware that her neighbours Nassau and Baden were negotiating at Berlin, swallowed her anger and went there too-in the person of Senator Thun. Thun was a supporter of Prussia, and so was replaced at the end of the year by M. de Guaita, who was not. In England the board of trade had tried to persuade the foreign office to protest against the preliminary squeezing of our ally, but Palmerston "was of opinion that there did not appear to be sufficient ground for a remonstrance.' 35 This was a little hard on Guaita, who was told at his first interview in Berlin, ' that Frankfort was little else than an entrepst for British manufactures, and that the Prussian government considered him [Guaita] in the light of an agent who was come to Berlin to fight a battle for British interests.' ${ }^{36}$ However, Palmerston agreed that

n Treitschke, Deutoche Geschichte, iii. 473, 875 .

nTo Palmerston, 4 June 1835. The 1835 despatches are in Foreign Office, Germany, 55-8.

"The treaty is in the State Papers, 1831-2, p. 165. It was the occasion of violent anti-British outbursts in the German press: Treitschke, iv. 401 seq.

2s Palmerston to the board of trade, 9 May 1835 : Board of Trade, 5, 42. Prussia had, among other things, granted special privileges to Cologne, thereby intercepting the Rhine trade below Frankfort.

a. Cartwright to Palmerston, 13 May 1835. 
if England were to abandon the treaty of 1832 - the necessary preliminary to Frankfort's coming to terms with Prussia- it could only be on condition that the fullest privileges compatible with the Prussian commercial system should be granted ' ${ }^{37}$ to our ally, and he used his influence in this sense. Prussia was really anxious to secure a treaty with Frankfort, if only to stop the brisk smuggling trade for which the free city was a centre. The adhesion of Nassau to the Zollverein brought the Prussian customs houses 'within a few hundred yards of the gates of the town on every side.' Therefore all the Frankfort merchants, 'British as well as other,' ${ }^{38}$ were now in favour of a settlement: so the business went forward without serious hitch. On 29 December $1835^{89}$ we agreed to abandon the mostfavoured-nation and navigation clauses of the treaty of 1832 , and next year Frankfort came into the Zollverein on satisfactory terms.

By this time England had realised that a new economic power hed risen in Europe, and curiosity about the working of the "Ger"manic Union of Customs,' as it was officially styled, and as to its possible future influence on our own commercial and navigation policy became intense. Now it happened that James Deacon Hume, one of the secretaries of the board of trade, had projected in conjunction with a utilitarian friend, John Macgregor, "a huge work on the commercial statistics of all nations.' ${ }^{41}$ Between 1832 and 1839 Macgregor was travelling up and down Europe collecting materials. He received some kind of roving commission from the board of trade and the foreign office, and in $1836^{41}$ began to report on the commercial situation in Germany and the effects of the Zollverein tariff on English trade. He was also feeling his way towards a tresty with the new power providing for some reduction of the duties on English manufactures.? In July 1836 he was present in Munich, with a watching brief, at the first tariff conference of the Zollverein. He discussed the question of a treaty informally with Kühne, the Prussian commissioner, who told him that if England

"To Cartwright, 7 July 1835.

25 Cartwright to Palmerston, despatch of 4 June ; private letter of 9 June 1835.

2 The treaty is in the 8tate Papers, 1836, p. 525.

t See Dictionary of National Biography, under John Macgregor. The article does not refer to Macgregor's diplomatio work in 1836-8.

"His misgion, which has not hitherto been generally known, was an anticipation of that of Dr. (afterwards Bir John) Bowring, three years later, which led to the publication of a famous report on the Zollverein. The documente relating to Macgregor's mission are in Board of Trade, 1, 322-4, and Foreign Office, Austria, 262-277. I have found no formal commission and imagine that all was arranged informally through Hume.

47 In April 1836 the Prussian commissioner at Leipzig, who 'only knows me as a traveller making statistical inquiries,' ventured the opinion that England might get the Prussian duties on textiles reduced in return for reductions on timber, linen, and, if possible, corn : Maogregor to board of trade, April 29. Possibly this is the discussion referred to by Treitschke, iv. 575, Palmerston liess in Berlin unter der Hand die Ermiissigung der Englisehen Holzzille anbieten, \&c. 
meant business she must go to Berlin and mast begin ' with a reduction of her corn duties to a fixed figure.' When Macgregor talked of other possible reductions Kühne ' took his stand upon corn.' It is interesting to find the fixed duty, which became the whig election cry five years later, in the mouth of a Prussian agent, though the idea was of course not new. Macgregor was equally unsuccessful when he sounded Baron Schmitz, the Würtemberger. Schmitz was all for free trade, but pointed out that the English duties on manufactures were higher than those of the Zollverein, which Macgregor could not deny. ${ }^{+3}$

While in Munich the wandering atilitarian came into touch with the Austrian chargé d'affaires, and in October he moved to Vienna. ${ }^{44}$ Metternich, recently awakened to the importance of those economic forces of whose working he was so profoundly ignorant, had decided in a general way that if Austria was to keep pace with Prussia she must enter into commercial alliances, and to that end must abandon her system of prohibitions and prohibitive tariffs." There had also been complaints from the shipowners of Trieste about the working of the Anglo-Austrian treaty of 1829 and about grievances arising under the English Navigation Law. Moreover, Aberdeen's treaty was about to expire. The times seemed ripe for the conclusion of a fresh one, which might deal with commerce as well as navigation, might be accompanied by some relaxations in the Austrian tariff system-without which it would be of little use -and so might provide a measure of compensation for the loss of that treaty with the Zollverein which could hardly be secured save by a radical remodelling of English commercial policy. Austria at any rate could not say that her fiscal system was already more liberal than that of England. Before the year was out Sir Frederick Lamb and Macgregor had started operations with Metternich and the endless bureaus and matually hostile officials of Vienna. ${ }^{46}$

Apart from the difficulties inherent in any negotiation with so imperfectly systematised a government as that of Austria in 1896-8, there were others arising from Macgregor's somewhat irregular position, his ignorance of and contempt for the details of the English navigation system, and the casual methods of Palmerston. During Macgregor's first visit Metternich asked him as a favour to construct an informal treaty. Upon this document, which contained some of the concessions that Austria was most eager to secure, the

43 Macgregor to the board of trade, $\theta$ and 14 July 1836.

" Sir F. Lamb, the ambassador, reports his arrival on 2 November to Palmerston.

is See Lamb to Palmerston, 2 November 1838; A. Boer, Die Finanzen Oesterreichs im 1\%. Jahrhundert, 175 sqq., and the shorter references in his Algemeine Geschichte des Welthandels, ii. 124-5, 205-7.

* The initiative came from the board of trade. See Macgregor's memorandum on the history of the negotiation to Baron Neumann, 14 May 1838. There are no references to the negotiation in Palmerston's drafts in 1836-7, and few in 1838. 
authorities at Vienna based an official draft that was sent to England for comment and criticism in July 1837 . The comments were incisive-apparently its origin was unknown in England-and Sir Frederick Lamb found himself in the awkward position of having ' to withdraw this project of our own proposing, in order to substitute for it an entirely new one, demanding additional advantages in return for the same concessions. This was not a very promising undertaking.' ${ }^{47}$ All Lamb's political vaticination and all Macgregor's profuse economical and statistical resources were brought to bear. The ambassador urged that the alliance, which among other things was intended to increase the traffic of the Danube, together with the suggested fiscal reforms, had important political bearings : they would bind the Austrian empire together, develop its resources, revive its friendly relations with England, contribute to the 'independence of all neighbouring states'-independence, that is, of Russian and Prussian influence-and 'give to Bavaria and Würtemberg a community of interests with Austria, and counterbalance the ascendency which Prussia had acquired over them.' 48 Macgregor informed the Austrians, in his most didactic manner, that nothing would save them short of 'a complete change in their financial and commercial system '; he convinced Hungarian landowners that a freer trade in manufactures was to their interest; and, retarming to the officials, who showed signs of liberal leanings in the matter of shipping but could not see their way to alterations of the tariff, told them that, after all, 'commodities and not ships were the objects of international commerce.' ${ }^{\text {t9 }}$ At length, in the epring of 1898, the Austrian government accepted the principle of tariff revision and officially signified its willingness to sign the treaty. ${ }^{\text {*w }}$ The abandonment of the traditional system of prohibitions involved the overthrow of a sacrosanct. edict of Maria Theresa, 'in fact a change in the fundamental law of the empire' $;$;1 hence the delays. The treaty was still in danger daring Maroh, bat Metternich signed it on 3 July and in due course it was ratified. Baron Eichhoff, the finance minister, was so angry 'that he declared himself to be on leave of absence' and took no part in the later proceedings. ${ }^{52}$

In its final form the treaty, by article 1, guaranteed perfect

$\therefore$ Lamb to Palmerston, 29 December 1837.

18 Ibid. 3 July and 29 December 1837.

* Naogregor's despatches to the board of trade and foreign office (Foreign Office, Austria, 275) of 12 July and 22 Norember 1837 ; also an enclosure, Macgregor to Kolowrati, in Lamb's despatch of 29 December 1837.

so In this condensed account I have laid stress on the infuence of the English negotiators on the Austrian tariff changes. That influence was clearly of the first importance, bat it could hardly have been effectire had not other forces been working in the same direction. For these see Beer's works, as above, p. 491, note $4 \overline{0}$.

"Nacgregor to the foreign office and Lamb to Palmerston, both of 28 February 1838.

z: Lamb to Palmerston, 3 July 1838. 
reciprocity of navigation dues throughout the whole of both empires. Article 2 guaranteed reciprocal treatment of goods, the produce of the two empires, including Austrian goods 'exported through the northern outlet of the Elbe and the eastern ontlet of the Danube.' This final clause had not been in the treaty of 1829 ; it was now inserted at the request of Austria, and, as it "was not at variance with the nevigation law of 1833,' Macgregor ' did not contend that it should be suppressed.' 's There was no formal provision for such cases in that law, but Frankfort furnished a precedent and the negotiators were much impressed with the possibilities of steam navigation on the great European rivers. ${ }^{54}$ Article 3 guaranteed equality of treatment in the case of those non-Austrian goods which might legally be sent to British ports, and extended to Austria the full benefits of the Navigation and Possessions Acts of 1833 and most-favourednation treatment for the future. Article 4 was revolutionary, but as its full meaning seems hardly to have been recognised at first, except by Macgregor, it went through without much discussion : "All Austrian vessels arriving from the ports of the Danabe, as far as Galacz inclusive, shall, together with their cargoes, be admitted into British ports exactly in the same manner as if such vessels came direct from Austrian ports.' This article, much desired by Austria, would allow Austrian ships to bring enumerated goods - grain or timber, for instance-for consumption in England from river ports on Turkish territory. It was in direct contravention of the existing Navigation Law. ${ }^{.5}$ Article 5 was also of moment. It allowed British vessels to enter Austrian ports as though they had themselves been Austrian, when coming from places not on British territory-a privilege that 'no previous treaty contains,' as Macgregor subsequently bossted. ${ }^{B \theta}$ In return for this solid concession the Navigation Act was again breached : the produce of the Mediterranean ports of Asia and Africa might be brought from Austrian ports in Austrian or British vessels indifferently. That this was illegal had been one of the original complaints of the shippers of Trieste, and Austria fought hard for the concession. It was made definitely conditional on the first part of the clause to prevent other nations claiming a like privilege without return. ${ }^{67}$ Articles 6-8 related to details of reciprocity-drawbacks, warehousing, and so

s3 Macgregor's explanatory memorandum, forwarded by Lamb, 3 July 1838.

st This point constantly occurs in the correspondence. A reference to it was usually inserted in the preamble of the later treaties of this type.

s3 J. G. Shaw Leferre, one of the secretaries of the board of trade, told the committe of 1847 (q. 33): "I rather believe that this line of policy originated in the inconvenience which was found to arise from the impossibility of completing ... cargoes . . . at some of these ports.'

- Commercial Statistics, i. 21. Austria had allowed our ships to do this before, but as a favour not as a right. See Labouchere's speech, 6 July 1840; Hansard, Iv. 469.

" Lamb and Macgregor's memoranda. 
on; 9 gave Austria most-favoured-nation treatment for the East Indian trade; 10 safeguarded the coasting trade; 12 dealt with the trade of the Ionian Islands. Article 11-which Macgregor regarded as the most important of all except 5-contained the mutual guarantee of most-favoured-nation treatment in all matters of commerce and navigation. It was to be strictly interpreted and promptly applied. The remaining clauses were formal.

The customs concessions that accompanied the treaty were published on $18 \mathrm{Jun} \theta 1838$. In the ceses of wrought brass and copper, cotton manufactures, earthenwere, 'fire engines,' glass, ironmongery, leather goods, linen, woollens, and some other articles prohibition was replaced by duties. ${ }^{58}$ In other instances duties were appreciably lowered, though not always so much as the English negotiators had hoped, particularly in the case of sugar. Yet the reduction in this instance was enough to stimalate the import trade greatly. ${ }^{89}$ It need hardly be said that the prohibitions had never been effective. There was an immense smuggling trade in English wares up the Elbe from Leipzig, to mention only one line of fraud. Indeed, the Bohemian manufacturers had asked for the abandonment of prohibition; they said they would rather compete with the legally admitted and taxed than with prohibited and smuggled goods. ${ }^{60}$ Besides introducing these customs changes, Austria modified her quarantine regulations in the interests of British shipping. Both parties were well satisfied with the first working of the new system, and Count Kolowrath told Macgregor that 'the revenue had gained even beyond his expectations from the change.' ${ }^{61}$

This is not the place to discuss at length the political significance of the treaty, which was probably not great. Lamb, very naturally, thought otherwise. He hoped that his handiwork, if successful, might prove 'the first step towards raising a solid bulwark against the further encroachments of Russia south of the Danube.' ${ }^{82}$ Macgregor wrote to Kolowrath about binding ' the countries lying below the Austrian dominions, south to the Balkans and north to the extremities of Wallachia, in the ... bonds of friendly alliance and of possible amalgamation with Austria.' ${ }^{63}$ The negotiations, he said, had "completely dispelled the illusions of "Young Italy"

ss The foll list is in Commercial Statistics, it 20.

" Macgregor's report to Lamb on the working of the treaty, 24 Qotober 1838. $\mathrm{He}$ had visited both Bohemia and Venetia.

- Lamb to Palmerston, 2 November 1836.

-1 Macgregor's report. Kolowrath with Metternich and a couple of archdukes sat on the inmost council of the empire. He hed all along favoured movement : Lamb to Palmerston, 9 October and 20 December 1836.

- To Palmerston, 3 July 1837, 3 July 1838, inter alia. Oddly enough the treaty was denounced in England as favouring Russian aggression: Miss Martineau, History of England, ì. 387.

- 1 November 1837; enclosure in Lamb to Palmerston, 29 December 1837. 
[in looking up to England] within the Austrian states.' ${ }^{64}$ But if Palmerston's opinions can be inferred from the rarity, brevity, and character of his despatches, he did not take his agents very seriously. As a rule he ignored the negotiations. He did back up Lamb's attempts to play Vienna against Petersburg, and wrote a slashing attack on Russia, a power 'more ambitious than strong, and not less wily than ambitious.' ${ }^{65}$ But one of his last despatches was a long essay on the sins and untrustworthiness of Austria, with the conclusion that 'England ought never for the sake of pleasing Austria to swerve from that course which her interests and her principles point out.' ${ }^{\text {of }}$ Clearly he had no illusions and no politico-economical imagination.

The treaty once concluded, it remained to be interpreted and regularised. Article 4-the Danube ports articlo-was not merely a breach of the Navigation Law, it was also a bad bit of drafting and led to a long discussion between the contracting parties. While this discussion was in progress, Poulett Thomson was unwilling to bring the matter before the house. ${ }^{07}$ A week after Labouchere succeeded him at the board of trade, in September 1839, an Austrian ship, with a cargo of Turkish corn shipped at a Turkish Danubian port, came into Gloucester. She was seized for breaking the Navigation Law, but let free on payment of a fine. Not until July of the following year did Labouchere move for leave to bring in a bill 'to enable her Majesty to carry into effect' the Austrian Treaty, 'and to empower her Majesty to declare by order in council that ports which are the most natural and convenient shipping ports of states within whose dominions they are not situated may in certain cases be considered' as the national ports of such states. ${ }^{\text {a }}$ The whole unbusinesslike proceeding gave the opposition an excellent opening. As to Article 5-which dealt with the shipping of Asiatic and African produce-it had been regularised in 1889 , as Herries contemptuously pat it, by a clause 'smuggled' into a customs bill on the third reading.

No sooner had Labouchere brought in his bill than Prussia, acting for the Zollverein, began to press for concessions. ${ }^{69}$ Palmerston was far too much occupied with French affairs to attend to the matter, Labouchere was out of town, and the treaty was drafted in

4 Macgregor's final report, 24 Ootober 1838.

"To Lamb, 8 Decenber 1837.

* To Lamb, 21 March 1838. When the treaty was discussed in the Lords, Aberdeen twitted the government with its new-found love of Austria : Hansard, xlv. 252).

- So Labouchere said in the speech quoted above. The whole opisode was threshed out in this debate by Herries, Labouchere, Colquhoun, Palmerston, and others.

- Hansard, lv. 469 . The bill became $3 \& 4$ Vict. o. xov.

- The foreign office documents referring to the business begin in Augu 3t 1840 ; but Bülow had openexl the matter earlier, so presumably his instruction 3 were based on the treaty rather than the bill. The chief documents are in Foreign Office, Prusaia 231 (1840) and 235 (1841), others in 232. 
friendly negotiation between Baron Bülow and John Macgregor, who had just sacceeded his collaborator J. D. Hume as secretary to the board of trade. ${ }^{70}$ The foreign office officials knew nothing of the course of the negotiations antil Macgregor and Bülow sent in their draft for transmission to Palmerston. Then a difficulty arose. Prussia wanted to have the Scheldt, as well as all the waterways from the Meuse to the Elbe inclusive, recognised as a natural outlet, and its ports, meaning Antwerp; as 'national' ports of the Zollverein. Bülow's argument was that the Scheldt was a branch of the Rhine, being connected with it by a natural waterway, just as was the Meuse, which England was quite willing to accept, and further that in practice the Rhenish riparian states had always reckoned Antwerp as a port on a mouth of the Rhine. ${ }^{71}$ Macgregor, never unwilling to stretch the Navigation Laws and perhsps outgeneralled by Bülow, admitted the Scheldt into the draft, though after some hesitation as to the legality of his action.7 Subsequently both Palmerston and Labouchere objected, and Macgregor had to argue in the name of ' $m y$ lords' against his own suggestion. ${ }^{73}$ The situation was rendered the more awkward by the fact that the law officers said that the Scheldt was quite legal, so that they could not be made use of in the explanation with Bülow. 'My lords '-that is, Labouchere-thought that the Scheldt was outside the spirit of the recent Act; that its inclusion would raise trouble with France; that we were already giving quite enough in return for what we got. ${ }^{74}$ Palmerston was apparently decided by the consideration that, if the Scheldt was a natural outlet for Prussia, a fortiori it was a natural outlet for France from whose territory it flows. ${ }^{75}$ He already knew of those suggestions for a Franco-Belgian customs union which became a definite scheme in the hands of Leopold I during the summer of 1841 . Obviously any precedent for a French claim that Antwerp should be reckoned a ' national' port would have given the king of the Belgians the best possible argument in favour of a proposal which, when it saw the light, was most distasteful to England..$^{76}$

The difficulties having been smoothed away, Palmerston and

to Since his Austrian work Maogregor had been engaged in unsuccessful oommercial negotistions at Naples. For the British grievances which he failed to remedy seo Commercial Statistics, i. 1196 sqq.

"Two memoranda from Bülow, August 1840 and Februsry 1841.

13 He pencilled his doubts in the margin.

13 E.g. Macgregor to Lord Leveson (of the foreign office) 19 September 1840. Palmerston wrote to his puzzlod eubordinates : "The fact is that I believe the Sobeldt was put into the convention at the board of trade while Mr. Labouchere was a way and without his knowledge and senction.'

"Macgregor to Lord Lereson, as above.

"See his letters to Sohleinitz, Bülow's deputy, 12 Ootober 1840, and to Bülow, 2 March 1841.

:4 Palmerston discussed the soheme in the latter part of 1840 with Lord William Russell at Berlin : Foreign Office, Prussia, 227. Aberdeen entirely agreed with his view : e.g. Aberdeen to Lord Stuart, 29 October 1842, Foreign Office, Russia, 279. 
Bülow signed the convention on 2 March 1841. British ships were to be free to enter the harbours of the Zollverein on the same terms as native ships, whether coming from British or non-British ports. This was not a new thing: Treitschke rightly says that the Prussian Navigation Laws were already far more liberal than the English; they made no distinction between direct and indirect voyages. ${ }^{77}$ In return for the guarantee that no alterations should be made in this rule during the currency of the treaty, England made the concession already referred to : she would treat Zollverein ships and their cargoes coming from all the ports between the Meuse and the Elbe as though they came from ports on Zollverein territory. The hing of Prussia and his allies were to place the import trade in sugar and rice-not the import trade generally-' upon the same footing as that of the most favoured nation' (art. 2); and any states that might join the Zollverein in the future were to enjoy the privileges guaranteed by the treaty (art. 3). Prussia's rights in the colonial trade remained as determined in 1824. Apart from the river ports clause there was no widening of the British Navigation Law. It is worth remembering that the treaty was bitterly denounced by List and the South German protectionist party as a public disaster for the Zollverein and as truckling to the sworn foe of German commercial unity.

Meanwhile the 'free trade' states of Germany that meant to remain outside the Zollverein or were in doubt as to the wisest course to pursue, recognising England's desire to encourage a policy advantageous to herself, also hastened to demand concessions. In 1840 Hamburg was discussing postal business with the board of trade, and in connexion with this negotiation Syndic Banks handed in, in December, a proposal for a commercial convention between England and the three Hanse towns-his government having understood that the Prussian treaty was already concluded and that by it (as was the case) Zollverein ships sailing from the North Sea ports would enjoy privileges as great as or greater than those of the Hanse ships themselves. ${ }^{78}$ There were rumours a loat a little later that Hamburg might after all join the Zollverein, rumours which help to explain the speed with which the negotiation was concluded. ${ }^{79}$ Indeed so rapid was the workmanship that the convention was actually ratified by the citizens of Hamburg, in April 1841, in a form which rendered it illegal under the Navigation Law, so that it had to be withdrawn and redrafted.

"Deulsche Geschichte, r. 458.

II Foreign Office, Hamburg, 88.

- Colonel Hodges, Consul-Gieneral at Hamburg, to Aberdeen, 2 November 1841 : Foreign Office, Hamburg, 91.

so ' It is now clear that we have gone farther than we intended-and farther than we can under the Navigation Laws' : Labouchere to Palmerston, 6 April 1841.

VOL. XXV.-NO. XCL. 
The official copy is deted 3 August 1841. As in the Zollverein treaty, English ships might now enter the Hanse ports on equal termas from whatever part of the world they came. Their cargoes also were to receive 'national' treatment. In return we made similar promises, but only in the case of ships coming from Hanseatic ports. Further we permitted all German goods whatsoever, that might legally be imported from the Hanse towns or any Elbe or Weser ports, to be imported in Hanse ships from the Hanse towns on the same terms as if they came in British ships. This clause overcame the difficulty arising out of the Zollverein treaty. There were no other working articles, the convention being merely supple. mentary to the treaty of reciprocity concluded with the Hanse towns in 1825 .

The cases of Mecklenburg, Oldenburg, and Hanover are closely associated with that of Hamburg. The four states had many interests in common. There were even vague schemes in the air for .a customs union between the Hanse towns, Hanover, Oldenburg, the Mecklenburgs, Holstein, Schleswig, and possibly Denmark, to be established ' on liberal principles, which would make a powerful .counterpart to the restrictive system of the Zollverein.' ${ }^{11}$ Mecklenborg-Schwerin was known to be divided. Already in 1841 Colonel Hodges reported to Aberdeen how Baron Lützow, the leading Mecklenburg statesman, had told him that they would soon be forced to join the Zollverein. "I inquired, "if England were to make any alteration in her existing corn laws, whether such a measure would make any chenge in the views of his government." $\mathrm{He}$ .answered, "It is very probable that it would do so." " 82 Next year Mecklenburg asked for an order in conncil extending to her ships the privileges enjoyed under the recent treaties by those of the Zollverein and the Hanse towns. This England was prepared to grant, but Aberdeen pointed out that certain differential harbour charges levied under local acts of parliament, not of recent date, could only be equalised by treaty. ${ }^{8}$ He accordingly forwarded a draft convention. The Mecklenburgers saw their chance. They promptly asked, among other things, that all the 'natural outlets' for the Zollverein trade should be recognised as 'national ' ports of Mecklenburg ; for 'it cannot be expected,' wrote Lützow, 'that the British government will now refuse to the Mecklenburg flag that favour which by the accession to the Zollverein could without doubt

" Fox Strangways to Viscount Canning, reporting a conversation with the Dake of Holstein-Augustenburg, 16 October 1843, Foreign Ofloe, Germany, 82. See also Bligh to Aberdeen, 18 January 1844, Foreign Office, Hanover, 42. This would have been an extension of the Steuerverein formed between Hanover, Brunswick, Oldenburg, and Bückeburg in 1834. Brunswick had in the meantime joined the Zollverein.

- 24 September 1841, Foreign Office, Hamburg, 91.

- To Hodges, 27 June 1843, based on a letter from the board of trade of 20 Feb. ruary 1843. These negotiations are in Foreign Office, Hamburg, 95 sqq. 
be obtained.' ${ }^{2}$ The rest of the negotiation, which was long, is unimportant. Mecklenburg carried almost all her points, and in the end her ships and their cergoes secured all the advantages of reciprocity 'when coming from the ports of Barth, Stralsund, Greifswald, Wolgast, and Stettin, or from the ports in the Trave, Elbe, or Meuse, or in any other river between the Elbe and the Meuse, or between the Trave and the Oder' (art. 5). By the signature of the treaty (1 May 1844) and of a doplicate for Mecklenburg-Strelitz, the latter state, which has no sea coast at all, found that one of its 'natural outlets' was Rotterdam. Oldenburg, who secured her treaty on 4 April 1844, was hardly so successful a bargainer. Her 'natural ontlets ' reached from the Meuse to the Elbe, but included no Baltic ports. $^{85}$ 'The impression upon my mind,' Hodges wrote, 'is that it was not expected that the advantages asked for by Mecklenburg and ceded by his Majesty's government would have been granted, and in case of refusal it would have been used as an additional motive . . . by M. de Lützow for arging a junction with the Zollverein.' ${ }^{86}$

In Hanover, as in Mecklenburg, there were Zollverein and antiZollverein parties. ${ }^{87}$ Their balance was eagerly watched by the English agents at the Hanoverian court.88 The accession of Brunswick to the Zollverein weakened the party of opposition and led to irritating negotiations with both Brunswick and Prussia during 1843-4. Meanwhile Aberdeen, advised by the board of trade, instructed our representative to " take every proper opportunity of encouraging the opinion that it will be more advantageous and more honourable for Hanover to maintain an independent position.' Bligh replied that this was what he had invariably done. ${ }^{89}$ In order to stiffen the Hanoverian opposition, every possible legal concession was made in the treaty signed by Aberdeen, Gladstone, and Count Kellmansegge in London, on $22 \mathrm{July} 1844$. Hanover, like Prassia, allowed British ships to come freely from all countries. This practice she undertook not to alter during the currency of the treaty. She also made some special reductions in favour of British goods in the so-called 'Stade toll,' levied on cargoes passing ap the estuary of the Elbe. ${ }^{90}$ In exchange she secured reciprocity, most-favoured-nation treatment, and a promise that all

" Lütsow to Hodges, 30 Beptember 1843. Lützor was in favour of joining the Zollverein, but was in a minority : Hodges to Canning, 10 Ootober 1843.

is State Papers, 1844.

" To Aberdeen, 7 May 1844.

" Hanover eventually joined in 1851, Mecklenburg not till 1867.

" Foreign Office, Hanover, 39 sqq. Seo especially Mr. Bligh to Aberdeen, 5 Jenuery and 30 Maroh 1843.

- Aberdeen to Bligh, 26 February 1844; Board of Trade to Foreign Office, 18 Febrarty 1844; Bligh to Aberdeen, 14 Maroh 1844.

- This toll looms large in the commercial diplomacy of the period. Its history from LD. 1038 is traced in a memorandum from Bülow to the foreign office in August 1840 : Foreign Office, Pruesia, 231. 
river and river-mouth ports from the Meuse to the Elbe and from the Trave to the Nemel should be treated as her natural outlets. ${ }^{91}$

The Mecklenburg treaty led to further demands from the Hanse towns, and the Hanoverian treaty equally stimulated the Mecklenburghers. Within a week of the signature of the former, Syndic Siereling, one of the few senators of Hamburg who favoured junction with the Zollverein, told Hodges that of course England would now extend to his government every privilege granted to Mecklenburg; and a month after the signing of the latter Lützow wrote to say that, if his government had ever supposed that ports as far east as the Memel could be conceded, it would have asked for them. Of course England would do as much for Mecklenburg as for Hanover. A mere declaration would suffice. ${ }^{9 ?}$

So the situation stood in Germany a year before the first failure of the potato crop and the beginning of the cataclysmic age in British commercial policy. The principle of 'natural outlets' had been stretched to breaking point. In return for the stretchings England had safeguarded the right of her ships to trade with German and Austrian ports direct from all parts of the world. She never gave so unqualified a right in return, though any vessels might bring any goods into her ports to be warehoused for re-exportation. The terms of admission to the colonial trade remained almost as Huskisson had left them. It was still illegal to bring non-European produce from European ports, except in the case of the Mediterranean trade; and Austria was the only foreign country to whose vessels had been recently conceded the right to share in this exception. ${ }^{93}$ The consolidating Navigation Law of 1845 provided for such concessions (§ 4). Also, for the first time, it extended the warehousing privilege to the colonies $(\$ 22)$, enumerating about forty free colonial warehousing ports. Some special privileges were granted to the shipping of Hong-Kong, and the penalties for breach of the law were lightened ; but these were the only changes of the least significance.

The other important commercial negotiations of the period that bear on the Navigation Laws may be dismissed briefly. The treaty with Russia of 11 January 1843 formally guaranteed to England certain rather limited advantages hitherto enjoyed 'in a great degree by sufferance,' ${ }^{94}$ and to Russia the use of Dantzig and other German ports on her own rivers according to the true geographical principle of natural outlets. Its interest, such as it is, lies in its connexion with the transition which was taking place in Russia, as in Austria,

"Hanorer was very eager to securo the use of these Baltic ports : Bligh to Aberdeen, 20 June I8 14.

"- Hollges to Aberdeen, 7 May 1S44 : Lützow to Hodges, 27 August 1844.

*t Turkey had long enjoyed the right : see above, p. 482, note 11 .

"Aberdeen to Lord Stuart de Rothesay, 24 November 1842, Foreign Office, Russia, 279. For the negotiations see 279-289. 
from a system of prohibition to one of protection, ${ }^{95}$ rather than in its navigation clauses. The Sardinian treaty of 6 September 1841 was the result of a wearisome negotiation by which England had hoped to secure a treaty of navigation and commerce. She failed on the commercial side, and even in the matter of navigation it was only with some reluctance that Sardinia was brought to sign a very colourless document. To the annoyance of our negotiators the Sardinian government-and particularly Charles Albert-could not be brought to accept an article based on the Austrian treaty of 1898, whereby we offered to give most-favoured-nation treatment in all our dominions and the right to bring goods into the United Kingdom from the Mediterranean ports of Africa and Asia through Sardinian ports, if they would allow our ships to enter their ports on equal terms with their own, wherever they came from. The Sardinians kept on asking why we would not give precisely what we demanded on this head; and the reply that our Navigation Laws would not let us do so failed to convince. In the end the treaty did little but secure reciprocity of navigation dues for the direct trade..$^{96}$ The Portuguese treaty of 2 July 1842 is an elaborate affair, covering a wide field, from the abolition of the droit d'aubaine to reciprocity of navigation dues. It freed the direct trade and opened the colonial trade of the contracting parties, within the regular legal limits so far as England was concerned. Certain extra differential duties, the result of a commercial quarrel in 1836-7, were removed. This appears to be the last case of active retaliation in our fiscal history, and as such may have some little interest. But in the history of the Navigation Laws the treaty is of no account. ${ }^{97}$

\section{J. H. Clapham.}

"see Sohulze-Gävernitz, Volkswirthochaftliche Studien aus Russland, p. 244 sqq.

- Foreign Office, Sardinia, 111-8. See especially Palmerston to Sir A. Foster, 26 Ootober 1839. Sir A. Foster to Palmerston, 20 Jenuary 1840, 17 February 1840. Mr. Aberoromby to Palmerston, 5 December 1840, 19 February 1841. Board of trade to foreign office, 16 January 1841, 12 March 1841. There had been an abortive negotiation in 1836 .

7 Foreign Office, Portugal, 521. The treaties of the period 1830-45 omitted from this account are Venezuela, 1834; Peru-Bolivia, 1837; Greece, 1837 ; Turkey, 1838 ; Ecuador, 1839 ; Bolivia, 1840 ; Teras, 1840 ; Denmark, 1841 (regulating the Sound dues); Würtemberg, 1841 ; Uruguay, 1842 ; Sicily, 1844 ; and the treaties with China. For various reasons none of these claim consideration in this connezion. 